\title{
MEN AND FEMINISM: FROM THE PRIVILEGE OF COMFORT TO THE UNEASINESS OF POLITICAL ENGAGEMENT IN FEMINIST
}

ISSUES

\section{Hombres y feminismo: del privilegio del confort a la incomodidad de la implicación política en cuestiones feministas}

\author{
Jokin Azpiazu Carballo* \\ * Universidad del País Vasco/Euskal Herriko Unibertsitatea \\ jokinazpiazucarballo@irq7.fr
}

Keywords

Men

Feminism

Subjectivity

Action

Palabras clave

Hombres

Feminismo

Subjetividad

Acción

\begin{abstract}
In the last decades we have witnessed many debates around new masculinities. However, reflections about masculinities and hegemonic masculinity seem to leave the trouble between men and feminism unsolved. Therefore, both academia and social movements demand tools to develop a critical view on this issue. This article deals with these questions based on two points of departure: in one hand, a series of academic and activist presentations in feminist and LGBT environments; in the other hand, an inquiry, conducted between 2012 and 2013 on the discourses around masculinities emerged from anti-sexist men's groups that appeared in Basque Country in the previous years. Privilege, oppression, identity, subjectivity and collective action are some of the matters that amalgam in the reflections this article brings together.
\end{abstract}

\section{Resumen}

En las últimas décadas se ha asistido a numerosos debates sobre nuevas masculinidades. Sin embargo, las reflexiones en torno a las masculinidades y la masculinidad hegemónica parecen seguir sin resolver la disputa de los hombres y el feminismo, y tanto desde la academia como desde los movimientos sociales se reclaman herramientas para poder desarrollar una mirada crítica al respecto. Este trabajo analiza estas cuestiones a partir de una serie de presentaciones de académicas y activistas feministas y LGTB sobre la compleja cuestión de los hombres y el feminismo así como de una investigación desarrollada entre 2012 y 2013 sobre los discursos de grupos de hombres contra el sexismo aparecidos en el País Vasco en los años precedentes. El privilegio, la opresión, la identidad, la subjetividad y la acción colectiva son algunas de las cuestiones que se cruzan en estas reflexiones y que este trabajo recoge.

Azpiazu Carballo, J., 2015, "Men and feminism: from the privilege of comfort to the uneasiness of political engagement in feminist issues", en Papeles del CEIC, vol. 2015/2, no 127, CEIC (Centro de Estudios sobre la Identidad Colectiva), Universidad del País Vasco, http://dx.doi.org/10.1387/pceic.14163 


\section{INTRODUCTION}

"New" masculinities have been widely discussed in the last decades, and in the last years the echo of those discussions has reached the realms of both academic and social debate in the Basque Country. Yet the reflection on masculinities and hegemonic masculinity seems unable to solve the dispute between men and feminism, and both academia and social movements reclaim tools to keep a critical and dynamic view at the issue.

I conducted a research during the years 2012 and 2013 that led to a MA dissertation entitled Men's groups and discourses on masculinities in Basque Country ${ }^{1}$ in which $\mathrm{I}$ analysed the emerging discourses on masculinities by the warmth of the few men's groups ${ }^{2}$ against sexism that had appeared in the last years in the Basque Country. Even as rich as the analysis and results of the research were the numerous presentations and debates with scholars, feminist and LGBT groups and activists. Those helped shaping some ideas around the complex relationship between men and feminism, taking men organized in antisexist consciousness groups just as a starting point. Hopefully, this will point to wider conclusions and hints in those intersection points were privilege, oppression, identity, subjectivity and collective action are amalgamated.

\section{DISCURSIVE INFLATION AROUND MASCULINITIES}

A couple of decades have gone by since the concept of "hegemonic masculinity" was elaborated by Raewyn Connell (1995) attempting to make an exhaustive analysis of gender in power relationships. Her work has been widely interpreted and cited as influential in the analysis of masculinity and the role manhood plays in power relationships, both

\footnotetext{
1 The work was presented as a final dissertation in the "Gender and feminist studies" MA ("Genero ikerketak eta ikerketa feministak" in original Basque) at the University of the Basque Country (UPV/EHU) under the supervision of Dr. Marta Luxan Serrano.

2 I consider important to clarify that when I am referring to "men's groups", I am only referring to groups that identify themselves as groups who address sexism from an egalitarian point of view. Those are usually groups that share a common ground with feminist groups and usually have some sort of relationship with those and their ideas. Therefore I am not considering groups that could be included in the so-called "men's rights" activist groups or other groups such as those who reclaim mandatory shared custody for children. I consider that those groups reinforce sexism and machismo and the goal of my research was to analyse and discuss the discourses of groups of men willing to overcome sexism.
} 
"between" the genders and "within" them ${ }^{3}$. The theoretic elaboration of authors such as Luis Bonino (2000) or Victor Seidler (2006), to cite just a few, has been as well very important, especially if we take into account that some of those wrote their main work in Spanish or had a pretty prompt translation, whereas Connell's hasn't. This is quite an important remark to do, since most of anti-sexist men's groups in Spain have mainly read texts and reflections available in their language, and thus the influence of those texts has multiplied easier than dissertations published in English, French, Dutch or any other language.

Needless to say, those different theoretical elaborations included as well different standpoints about the issue, from analysis of power that included all levels of society (micro-meso-macro), to those centred in micro levels of interaction between men and women, all through identity and intimacy centred analysis. Depending not only in the nature of the analysis but also in the intentions and interests of the readers, different approaches to the issue of masculinity have been available, from those more centred in identity formation issues to those focused on subjectivity and power.

I will refer to identity as the process in which human beings are given attributes that become part of their experience of the social world. The experience of being a $\operatorname{man}^{4}$, for instance, has been a changing one and has been determined by differences in culture, time and geographic location (to name just a few). It could be said that being a man is a different experience now and then, and that men are experimenting, at least in the global west, with a wider realm of possibilities about masculinity and its performance.

3 The contribution made by Connell when analysing masculinity under the light of gender systems and networks rather than doing it as static identity constructions remains vital here.

4 The use of the words "man" and "woman" and their plural forms in this text need a clarification: I am not referring to those categories as if they were undisputed. Therefore, I am not willing to present the notions of "man" and "woman" as undeniable realities and "masculine" and "feminine" as social constructions. I advocate for a de-essentializing use of those categories, following the work of scholars as Butler $(1993 ; 2006)$ and FaustoSterling (2000). It is important, then, to clarify that when I refer to men or women I am conscious that behind those categories relies an amalgam of experiences and material realities that widely exceed the terms that contain them. However, a non-definitive, strategic use of those categories is still needed in my opinion in order to be able to articulate politically effective conversations. Mostly, with "men" I will refer to people (usually) socialized as men and perceived as such and with "women" to people (usually) socialized and perceived as such. 
Following the definition by Rosi Braidotti (2000; 2004), subjectivity would refer not so much to the specific position in which our identity construction "leaves us" but also to what we do and how we deal with those positions, both individually and collectively ${ }^{5}$. The arena of subjectivity is therefore intrinsically related to action and the ability for action can be understood as access to (different types of) power. Although both forms of analysis (identity-centred and power/subjectivity-centred) are necessary to understand social realities and change them from a feminist point of view, many approaches to masculinity have prioritized the study in of identities leaving aside many material and non-material aspects linked to power. Therefore, a slanted view, an incomplete picture of masculinity and the way it is changing is presented.

This can be pointed out as one of the key issues that defines the relationship between men and feminism. The last decades have seen and increasing interest in the study of masculinities and their changes. Probably not such attention has been paid to the changes (or lack of changes) in the power balance between men and women, the material effects of these inequalities and the resistance points in which they tend to tie up.

Accompanying this, as explained by Foucault (2009), the emphasis put in change when analysing historical facts may have trapped the study on masculinities in some sort of a-critical idea of progress in which any change is taken as granted, and any variation is seen as positive. Still, we may be able to throw a different light on this issue if we emphasize subjectivities and power balance. Different conclusions leading to different proposals for change could be then drawn.

\subsection{Studying men's groups and discourses around masculinities: who's that man?}

Many concerns derived from the abovementioned reflections were considered during the analysis of the discourses on masculinities

\footnotetext{
5 It is important to note that the notion of subjectivity as presented by Braidotti refers to the project of constructing a feminine feminist subjectivity, this idea being in a close connection with the Deleuzian take on desire and power/potency. From the point of view of the sexual difference advocated by the Italian philosopher it would be absurd to use the same notion of subjectivity to refer to men and women, since the very standpoint is the irreversibility of both. However, this notion proves useful to keep the concept of identity attached to power, fuelling its political strength.
} 
emerging from men's groups activism in the Basque Country. The main source of data for analysis used during this investigation were written outputs by these groups, such as manifestos, communiqués or pieces of blogs ${ }^{6}$, which were analysed making use of a critical discourse analysis with feminists perspective methodology (Baxter, 2004; Lazar, 2007).

One of the first elements to emerge from the analysis of those texts was the presence of "new masculinities" as opposed to "old masculinities", presenting them as total alternatives to traditional masculinities. Here, "traditional" is also presented as a synonym for "hegemonic", which can lead to confusion, since hegemonic is a term clearly derived from powercentred analysis, while "traditional" can centre on identity as separated from power and stresses the idea of progress as an always improving process. Probably, this staging of past versus present/future remains a good way to make change look positive and desirable, but still leaves aside the focus on what remains from the old in the new. Besides, it pays no recognition to different forms of embodying masculinity that have been present in other moments of history, probably enacted by men outside the norms of hegemony, like queer men, masculine women, small men, weak men, ill men...

This relates to an idea surfacing in many of the texts: change must be voluntary and made visible. It must rely on critical analysis and review of attitudes and ideas on what masculinity is and how it is performed. Clearly, this is a good starting point for a political goal as important and necessary as having more men joining the "quest for equality". However, at the same time it ignores the changes in masculinities that have not been voluntary, but imposed to different people because of many reasons that make them "not valuable" for masculinity". Change is

6 Seven documents were analysed in depth: four writings produced by four different autonomous groups, and two documents produced by institutional initiatives related to the issue. It must be noted that the analysed corpus is small, as the production of new materials by the groups is. It is very common to see those texts reproduced in different groups' blogs and pages, but not so common to see new texts being published. The deep scrutiny of the texts, then, pointed to exploratory conclusions used to open debates in various forums.

7 To cite just an example, Paco Guzmán and Lucas Platero (2012) have written about the intersection between gender, sexuality and ableism, exposing how embodying disability and being perceived as handicapped makes many men to be understood as less manly and unconnected to sexual desire. The text puts emphasis in non-normative sexualities from this point of view and although is not exclusively centred in men, it is a good example of an intersectional view on masculinity. 
therefore visible when it is local white straight men that voluntarily enrol on it, but not when subaltern groups (Spivak, 1996) are changing; their experience is not considered. This idea is repeatedly underlined by the subjects of appeal in the analysed texts, which clearly are defined as straight cis $^{8}$ men living in couples and in most cases parenting children. Specific issues around these "lifestyles" are constantly named ("we are more eager to be supportive with women in general terms than with our partner", "the new man has started a process to re-think the relationship with his sons and daughters", "we have to educate ourselves and our children"...) whereas there is no specific call to other groups of people such as homosexual men, trans men $^{9}$, migrant men, masculine women...

\subsection{The new man}

Underlining the voluntary changes in men can channel the creation of a new group identity, which is often named in the texts in vague ways as "men who care", "men who want a change", "egalitarian men", "new masculinities" or "alternative masculinities". The binary vision on sex and gender operates here as a boundary to new configurations of gender that could question the need to be identified as men (at least as a longterm goal), and holds to a strap that appears both as strategic and ontological in different discursive moments.

Becoming a "new man", but still holding to the very idea of manhood and masculinity as unable to be eliminated reflects, in one hand, the necessary point of departure for men-identified people to feel the call for change that these groups try to lead. In that sense, we could understand this essentialised notion of manhood as strategic. But, on the other hand, it also reflects how manhood and masculinity remain still a very important hook for identities, a category without which it is very difficult or impossible to operate political discourses around masculinity by the studied groups.

8 For those unfamiliar with the term, Cis refers to the condition of experiencing one's gender identity according to the one assigned at birth; therefore a person who was assigned as a boy at birth and gets on living as a man would be considered a cis man. The term responds to a strategy of trans communities to flip the stigma on trans people, who were the only ones to carry a prefix - trans- related to their gender experience.

9 The reflections around masculinity and power by trans men -(Hoppe, 2008) or (Galofre, 2014), among many others - can be really helpful. They contribute to consider different aspects of masculinity and deconstruct male identities without leaving the focus on power away. 
Nevertheless, it is important to note that the debates on identities, subjectivity and action in both academic and activist feminist environments have led to a questioning of the very idea of womanhood and identity in feminist practices in the same geographic area ${ }^{10}$. Far from suggesting that these debates have reached any point of consensus inside the aforementioned communities and feminist movements, it is clear that they have been important and unavoidable debates. They have forced different groups to take up several stances, usually confronted, but most of the times made visible and explicit. From these debates and with the intention of overcoming the impasse (Gil, 2011; 2015) a series of (often opposed) proposals like the coalition politics of Judith Butler (2004) or the strategic essentialism of Gayatri Spivak (1996) have emerged. However, the observation of the analysed documents does show no presence of such debates. The writings present a default position in fixed identities and a conceptualization of gender as a layer that superimposes (socially) the sex (as a material reality isolated from culture).

Identity, nonetheless, seems to be a key point to understand the discourses emerging from those practices and groups. The formation of a new masculine identity, the new masculinity free of suspicion, the new man who somehow belongs to the group of "the few good men", appears as an important feature. This is made translucent through the use of expressions directed to underline the differences and also through the specific and confuse use of pronouns, sometimes referring to men in first person plural ("we men have to understand", "we need to change"...) and sometimes in third person ("men have to understand", "they need to be clear about", the emphasis is mine).

There is probably an understanding of feminist critique of masculinity and men's hegemony in society as a personal attack that puts men under the target operating here (somehow fuelled by media and popular culture's readings on feminism). This feeds the need for some men to create and inflate a new identity, a more acceptable one. Actually the very idea of being under any kind of suspicion seems a very uncomfortable spot for men, since hegemony is clearly not only about making great use of power but as well about not being questioned for it.

10 About feminist debates on identity and subjects of change in the Basque Country, see Esteban and Amurrio (2010), Zabala (2008) or (in basque language) the recently published Epelde et al. (2015). 
This way, even if men's group's commitment to change is fuelled mainly by ethical considerations, it is important not to forget that an underlying goal related to identity-creating and safety can be as well involved.

\subsection{Motivations for change: where is power, and where does it go?}

The motivations behind change and the need for it (and the directions in which it needs to be developed) are equally diverse and sometimes even contradictory among themselves. The main motivations remain, as I said before, ethical. The expressions that underline the ethical commitment are the most present ones ("we have a moral obligation to...", "it is the responsibility of men to leave aside such attitudes", "we must make a bigger effort"...). In that sense, the word "must" is very high in the list of concordances the texts produce ${ }^{11}$.

Aside with the moral/ethic motivations, some other types of discourses appear and those are linked to opportunity, advantages and winnings. The idea of men needing equality as women do and therefore being beneficiaries of the changes in gender based inequalities is a recurring one: "we must understand this will be a benefit for all", "women's liberation does not suppose any harm or loss of rights and freedom for men"... Therefore, the system that generates gender inequality is presented as affecting both men and women. This has different implications that must be understood in their ambivalence and multiple effects, in order not to simplify the debate.

In one hand, it must be understood that presenting any kind of change as an advantage for those involved can be a good way to get people engaged and help develop a commitment for change. Again, this seems a fair strategic approach to take. But, in the other hand, this take on motivations moves away from the ethical approach described before, and more even, it neutralizes the question of power. If power relationships are to be changed and subverted in the search of equality, that leads to suppose that someone is going to lose power and someone is going to gain it. Therefore, change is not always an advantage for everyone, which does not imply that it is not fair, necessary or ethically desirable.

11 It would be interesting to discuss how the notions of politics, morale and ethics are understood and disposed in the emerging discourses. It is my opinion that it could exceed the goals of this article. 
If we take into consideration the debates on power and intersectionality (Crenshaw, 1991; Platero, 2012) so present in feminist activism and academia in the last years, we will realize that one of the drawbacks of talking power as a diffuse element has been precisely making it more invisible and difficult to point at. Feminist activism has shown the political importance of taking that risk, but at the same time the significance of not overlooking this side effect.

In the precise case discussed here, it is important to acknowledge that some of the groups and initiatives analysed are inscribed in the institutional and government arena, a realm in which talking about common benefits is crucial. Governance has actually a great deal to do with not discussing power and power relationships but presenting a calm and harmonic picture of social life. But the assumption of the "common benefits" discourse by other groups as well can show the need to moderate the speeches about power and make change a positive element.

In the other hand, the affirmation of gender systems generating consequences in both men and women can lead to some groups and masculinities theorists to present men as victims of patriarchy. This has been a key element and an important point of disagreement between men's groups and feminist activists ${ }^{12}$ as well as among men's groups' activists. To present (or not) men as victims has shaped different positions in that debate and has led to disagreements in the theoretical level as well, with some activists and theorists proposing that men need a different theory than feminism for their "liberation" process.

\subsection{Drawbacks and privileges}

The aforementioned debate necessarily takes us to the issue of drawbacks and privileges and how they are presented and dealt with in the context of the groups and initiatives observed. There are very few references in the texts to privilege - referred to by Connell as patriarchal returns (1997)-, sometimes presented as diffuse ("we need to increase

12 In January 2014 I attended, along with some other 40 people, a meeting in San Sebastian, called by a series of men's groups to bring together men's groups activists and feminist activists. Many issues were discussed during the meeting, one of them being the victimization of men, that some feminist activists (and some of the men's groups activists as well) did not find appropriate and thought of as a manipulation and a deviation of focus from the issue of power. Some ideas emerging from that meeting are elaborated in the second part of this article. 
the number of men ready to question the privileges that patriarchy may give them", the emphasis is mine). Many more references point to disadvantages and drawbacks, more clearly formulated: "negative consequences that gender roles bring", "sexism harms women but also us men, blocking us from being emotional, empathic and apt for taking care of others and ourselves". This last quote may explain that one of the essential elements of analysis may rely on the focus. If we step out of the masculine standpoint, we may see "not being able to take care of others and ourselves" as a drawback for those "others" who do not get the attention and care or for those who have to take care of us because we seem unable to do so. Opposed to that, if we put the focus on men, we may see it as a drawback for men's emotional development, and therefore victimize our position.

The issue of emotions and the (lack of) ability to express them appears many times as one of the main disadvantages that men suffer due to the influence/determination of patriarchy. In the context of the data analysed, the lack of emotional life refers to the difficulties of experiencing and expressing the emotions that have been labelled as feminine (Lupton, 1998), but it is presented as a more general statement: men being denied the emotional world. "Men's traditional emotional isolation", "we are banned from being emotional"... This approach to emotions implies that the (banned) emotional world is the world of the feminine emotions and therefore equates "emotion" with "feminine". Some other emotions expressed legitimately by men are not discussed (anger, ambition...) and stay invisible as if they were not emotions. Therefore, men's not being permitted to express "feminine" emotions is denounced, but the privilege of men having the monopoly of expressing other emotions remains undisputed.

In relation to this, the idea of men acquiring abilities that allow a wider range of emotions remains an attractive idea of growth and well being, while the idea of discussing the privilege (that should probably entail losing a field of expression of emotions such as anger, aggressiveness, indignation or ambition) is not discussed. Many feminist authors such as Mari Luz Esteban (2011) have underlined that the expression of masculine-categorized emotions by women remains a taboo and is seen as an indication of mental instability or hysteria. At the same time, the expression of feminine-categorized emotions by men is seen as a sign of adaptation to the times, personal growth or maturity. It is more often a 
key to social acceptance than the opposite. In that sense, the notion of progress must be put on hold to understand the social changes as biased by the power positions. In the current contexts, in which masculine identity operates from power positions, changes that do not put those positions at stake are allowed while changes or disruptions in feminine identities remain a risk.

Through the ways in which men's groups and some initiatives around masculinities present change and the need for it, some inflation on the concepts of masculinities (in plural) and new masculinity can happen, as a by-product of an analysis and plan of actions more centred in identity than in subjectivity and power. Actually, it is not by the actions and proposals of those groups that these notions are inflated and filled with optimistic meanings. It is the combinations of those and the dynamics of appropriation of the late patriarchy that makes this effect possible.

The notion of hybrid masculinities (Bridges and Pascoe, 2014) can be helpful to understand the underlying sense of some changes in masculinities. This notion operates as a critical review of the "new masculinities" concept and tries to address visible changes in masculinities as sometimes strategic, in the sense of those changes being manoeuvres of re-situation of men in front of the new configurations of gender systems. The idea of hybridization (that includes elements of different models of masculinity, from hegemonic to alternative) can be helpful to understand the production and reception of some discourses around masculinities, but must be used carefully, since it may suggest that those strategic choices made by men are always conscious.

Albeit interesting, the conscious/unconscious pairing can actually be a trap to avoid placing the debate in terms of power by centring in the intentionality of the actions and positions taken by men (deliberate or unconscious) rather than in the effects of those. In this sense it can be helpful to think about those as advantages and drawbacks calculations in the area of power relations. These can be conscious, unconscious, or include different levels of both, and must be understood in the actual social contexts in which hegemonic masculinities are not "popular" anymore and change may be a strategy for sustaining certain levels of power. The idea pointed out by Connell that hegemony is actually a dynamic concept and therefore what is hegemonic in each moment can change and evolve into something different seems important here. 
Actually, one of the limits of the notion of hegemonic masculinity proposed by Connell (1995) can be that even though it was conceived as a power-centred notion it has been widely used to identify differences among men from an exclusively identity point of view, often losing its attachment to power analysis. Therefore, studies around masculinities have been focused in pointing at changes in masculinity as a way to define "new ways" of being a man. The "old man" is left in a stereotyped place, defining hegemonic masculinity as a very particular set of attitudes (and even looks) that are in a great degree associated with the past. This model appears as such an "extreme" incarnation of masculinity that practically no man can see himself reflected on it.

Re-gaining the power analysis of masculinities and setting the look in its effects more than in its forms will probably allow us to articulate more complex readings on masculinities and power that can be useful in the present contexts where hegemony and masculinity are not so easily operated through roughness, risk-taking, extreme violence and fear to homosexuality ${ }^{13}$. In present societies, new configurations in gender power relationships reclaim new ways of conceptualizing the assemblage between masculinity and hegemony.

\section{RE-LOCATING THE QUESTION, THINKING FORMULAS AND POSSIBLE ARTICULATIONS}

The conclusions drawn in the first chapter of this article derive from my MA final dissertation presented on September of 2013 in the University of the Basque Country. Since then I have been invited to some debates, presentations and workshops around this issue, mostly due to the publication of some interviews and dissemination articles in feminist and gender-sensitive press. I have tried to make the most of those meetings with feminist activists and debates by recording them and taking as many notes as possible to try and look for new directions and ways of wringing the contents and ideas contained in the dissertation.

I must recognise that many of the ideas reflected in the dissertation itself were the result of conversations and debates with many feminist and LGBT activists in the last years, so it seemed more than necessary to continue with this work of sharing thoughts about men and feminism

13 Those characteristics have been usually pointed out to describe hegemonic masculinity and the way it works. 
after the research was presented. I must recognize, though, that keeping a balance between sharing my thoughts on this issue and the (small and limited) impact on media and other representation spaces put into question my own thoughts on the relationship men could explore with feminism. Probably, the idea of assuming that tension as inherent to the fact of having being socialized as a man and behaving and being perceived (mostly) as such, helped me think about discomfort as a productive and creative space and probably the only space in which we can relate to others in a political sense (Garcés, 2013).

Therefore, some of the ideas presented here are fruit of the collaboration and collective debates with many feminist, LGBT/queer and men groups' activists as well as with different scholars, academic friends and student colleagues ${ }^{14}$. The main focus adopted in those debate sessions started revolving around the contents of the very dissertation in a presentation type, and regularly a more open-ended debate form displaced the presentation format, where issues were centred in the question of men and feminism more than on men's groups or masculinities. Therefore, in the following paragraphs I am going to try and give some hints on these debates, attempting to put my finger on key issues that have shaped the relationships between men and feminist activists and groups in my present context.

\subsection{Feminism for those who want to get involved, safe spaces and challenges}

It appears that most of the men taking part in men's groups and showing interest and responsibility about feminist issues and sexism in the Basque Country come from quite a common background but slightly different experiences. During the first session of a workshop entitled "Men and feminism, articulating profound relationships", in which men and some women took part I asked the men in the group to explain their interest in the workshop and the reasons that had brought them there ${ }^{15}$.

14 I would like to thank, among others, Marta Luxán, Matxalen Legarreta, Barbara Biglia Esti de Miguel, Mari Luz Esteban, Bilgune Feminista activists, Komite Arroxa collective, Women's House in Arrasate, Bertsozale Elkartea association, La Kelo, Joxemi Zumalabe Foundation, Ibon Egaña, Sejo Carrascosa, Sara Barrientos and Miriam Aleman from Candela collective, Alcachofa group and all the feminist activists from Barcelona and the Basque Country among others.

15 This workshop was organized by Women's House in Arrasate (Basque Country) in November 2014. Around 20 men took part in the men-oriented part of the workshop and 10 more women joined in the mixed part of it. I facilitated the workshop. 
A common motivation to attend the workshop was being part of social movements or activist environments. The process of getting interested with and involved in feminist issues was seen as part of their (wider) commitment to social change. Therefore, we could describe most (if not all) of the participants as progressive or left wing activists ${ }^{16}$. This confirms the idea, described in the first part of this article, that most of the times the main motivation for men to get involved and/or organize in groups to approach sexism remains ethical.

However, when asked about their relationship with feminism based on their own experiences, a wider amalgam of responses emerged. A continuum was sketched, placing two ideas in the extremes: the idea of a safe space, in one hand, and the ideas of challenge, initial fear and oddness, in the other. The notion of intersectionality seems suitable to explain the situation. The intersectional positions occupied by different men in different moments and spaces were in a great deal responsible for their perception of feminism in the past (the question was placed with an emphasis in their first contact with feminism, and its evolution). Those who had (mostly) experienced a privileged position were placed mainly in the "fear/oddness/challenge" side of the continuum. Those who had not experienced such a high level of power situated themselves closer to the "safe space" side of $i^{17}$. Likewise, this was linked with their identification with the terms "man" and "masculine", that some of the participants refused as a term explaining their identities but embraced as a term that explained their positions and relationships with others.

We could point to sexuality and gender adequacy/passing as two of the most determinant factors to understand this situation: most of the people who felt their experience with feminism was related to challenge were straight and their masculinity performance was accepted as standard (according to their own account of experiences). Contrarily, some other participants expressed that their relationship with feminism was shaped by the idea of having found a safe space, be it by being

16 Social and political activism in the Basque Country has been reported as very high, with elevate levels of commitment to several causes, like progressive nationalism, unionism, ecology, feminism or participatory democracy among others. Some recent studies locate the level of participation in social and political associations in between $30 \%$ and $40 \%$ (Villarroya and Goig, 2003) although numbers may vary depending on how the concepts of association are defined.

17 Of course, shades of grey were very present and the idea of continuum as lineal may not help to show the diversity of experiences and their variability. 
surrounded by feminist women, be it by reading matter on sexism or gender stereotypes. These men defined themselves as gay/queer or gave account of expressing and embodying, especially during their childhood and adolescence, gender performances that were not accepted as "utterly masculine". Other factors such as the closeness to feminist activist groups (in university, for example) or familiar conditions that shape the experience towards the agency of women (such as being the only boy among sisters) amass the ability to explain the positions towards feminism.

However, switching the focus from identity to subjectivity and power can be helpful once again, since all the men expressed having made extensive use of their privilege as men. Actually, all of the men who positioned their experience in the "safe space" end of the continuum underlined as well the importance of the challenge feminism had been for them, and the need to revisit their positions and attitudes towards gender issues ${ }^{18}$. This vision was shared also by many women in the room who affirmed feminism was always more than just a safe space and also challenged them in their visions and acts. Finding common grounds for discomfort as a motor for change seems then a feminist principle that could guide somehow the relationship between men and feminist activists and groups.

\subsection{The need to re-think action and visibility}

The above-mentioned hyper-visibility of new masculinities as a changing unit is intimately associated with the visibility men occupy in the social arena. Starting from media representations ${ }^{19}$, this has been a common point of tension between men's groups and feminist groups, a tension made visible in just few occasions, due mainly to the fact that both

18 The difficulties of people living non-normative sexualities to address feminist issues have been widely discussed in both feminist and queer/LGBT spaces. Actually, some argue that non-normative sexualities (especially gay men's) can easily fit into hetero-normative settings reproducing similar structures. This reproduction is often seen as a way of liberation through integration, in what has been named as homonormativity (Duggan, 2003).

19 Some media have been paying large attention to the proposals and agendas of some of men's groups and institutional initiatives around new masculinities. It is important to clarify that the Basque Government has since 2007 a program called "Gizonduz" (could translate as a play on words between "being better men" and "becoming men") that seeks enlarging the implication of men in gender equality issues and promotes different initiatives through diverse government structures, specially local government equality departments. 
groups (anti-sexist men and feminist women) have often the feeling of finding themselves "in the same boat"20. However, sharing allegedly common goals does not prevent them from having on-going conflicts, especially when different power positions are articulated in the social spaces. Such is the case of media's representations and their differentiating attention to the activities of men's groups and feminist groups.

This idea brings a dilemma that has been a common source of debates in men's groups. It is no other than the one between publicizing actions and seizing the social space (as men) in doing so. In one hand, the goal of those groups remains to provoke social change and therefore publicity and dissemination are important to those goals. In the other hand, this can easily result in unequal sharing of space, and deals with a dangerous effect, making some discourses more legitimate as they are identified with and fuelled by men's voices. The positive effect of having the discourse delivered "out there" clashes with the reification of women's voices as non-legitimate. Extensively, other men interested in feminism that do not take part in men's groups activities and several feminist activists have also expressed their concern about this issue.

Two ideas collapse: men have to "do something" about sexism and men are doing "too much about it" (better said, appearing to do more than we actually do). This clash could be presented in two opposite sides of a line, but it can easily lead to a blockage, unless we put into question the ideas of action ${ }^{21}$ and activism themselves. The general way of understanding action in social movements has been strongly fuelled by the idea of conscious, propositional and autonomous action. This feeds from the idea of subjects as independent and self-responsible of their actions rooted in the masculine notion of subject and citizenships widely critiqued by feminist theorists (Mackenzie and Stoljar, 1999, among

20 The quote corresponds to one of the participants in the "Gizonak eta feminismoak" ("Men and feminisms") meeting in San Sebastian, in January 2014 (the event was organized by "on:giz, berdintasunaren aldeko elkartea", group of men advocating for equality). The expression is of common use in Basque and Spanish languages and the use of it was recurring during the debates once it was mentioned for the first time. It expresses the overall positive yet complicated and controversial feelings on cooperation and common goals between anti-sexist men's groups and feminist women's groups and activists.

21 Action as a relational idea that presupposes both equality and difference has been discussed by Hannah Arendt (1998), among others, and can be a good starting point for a reflection. 
others). The idea of action, then, demands visible and public effects and ignores the affects involved and the changes in the so-called "private" arena.

However, re-thinking action would not exclusively mean to locate men's participation in feminist issues in the "private" and individual/behavioural ground. Once again, two main tendencies are identified, one of them underlining the importance of structures and systems in gender-based power unbalance and the other one placing the motor of change in individual behaviour and personal transformation. Most of the men's groups activities have focused in the second aspect of this pair, to the point that most of the proposals made by them revolve around the responsibility men have to develop in household and childcare. However, the positive type of action here ("getting our hands on that", "start wearing the apron") do not come with a similar set of proposals about how to "get our hands off that", how to decrease privilege and power in both "public" and "private" spaces. The fact that men are slowly getting more involved with childcare (Defentsoria, 2003) but not consequently reducing their external work time or engaging in paternity leaves can illustrate my point here.

In light of the above, re-thinking action must comprise both re-thinking the idea of subject and the relationship between subject and structure. This will allow avoiding both the resource of "blaming the system" and the neo-liberal take on subjectivity that underlines that individual change is in our hands (and that it is actually the only feasible change). Furthermore, the idea of collective action as expressed in activism has to be re-defined in several senses: is it possible to engage in actions that are somehow conscious but passive at the same time? Is it possible for men to get involved with feminism from positions other than notoriously active and avant-garde? It appears as a recurring debate, present as well in other times, places and movements, such as the civil rights movements or in the fights of undocumented immigrants in which white people have gotten involved. In both cases the debates about (white) privilege have been indispensable.

\subsection{Finding formulas to embrace responsibility}

Following the debates on types of action, the formulas through which men can get involved are often discussed. As I shortly explained before, 
the emergence of anti-sexist men's groups has been in a great degree fuelled by the creation of the aforementioned program "Gizonduz". The launching of the program was followed by a greater attention (and funds) to activities addressed to men, such as workshops on romantic relationships, campaigns on the importance of care or debates on housework. Several men's groups were created, some of them being a direct result of the program activities, some of them an indirect result of it (propelled by the atmosphere of the moment) and some other just happened to be in the same moment in the same place. However, lately, the idea of "men meeting men to discuss gender issues" has been put into question, not as a valid option in itself, but as the only formula available.

There may be different approaches to having a group of "equals" gathered around an issue. Women's consciousness raising groups and feminist groups are commonly referenced when discussing the creation of men's groups. Those were (and still are) created from common readings on the experience of oppression by the women taking part of the groups. However, thinking men's groups as a reverse of women's groups could lead to different conclusions: mainly, we could talk about the shared experience of oppression suffered by men as a result of patriarchy. This, as I said before, results in presenting men as victims and even sometimes matching this oppression with women's oppression. Needless to say, this creates evident tension between those who support these readings on oppression and feminist activist flipping the focus from oppressions to privilege, the common experience of most of the participants in those groups is actually sharing a privileged position and the desire of deconstructing or renouncing to it. This relocates the goals of the group in a more committed position, but of course makes it less appealing for most of the men.

Nonetheless, the very formula of men's groups as the (only) form of involvement in feminism for men draws different questions and dilemmas that need to be solved. Added to the difficulties of identifying a common experience (due to intersectional flows of power) and the inaccuracy of placing men's groups as a reverse to women's groups, the question of responsibility introduces a new element in the equation. The existence of the groups responds to a question of liability that has been pointed out by many of the participants and activists as a key element: men have to be responsible for their positions in power schemes 
provided by gender systems. Indeed, this aspect has been marked as an important contribution made by men's groups. As pointed by Audre Lorde (2007), dominant groups have to understand the importance of reviewing their position in oppression systems and it would be a trap for the oppressed to have to take the load of explaining what has to be done to reverse the effects of oppression.

Therefore, responsibility comes with a necessary autonomy: men have to be responsible of their own change, and this implies reading, getting information, debating and placing themselves in a conscious position towards gender issues, without waiting for (feminist) women "to tell them what to do". Howbeit, the autonomy of men in their search for ways of enacting social change can propel an effect of isolation towards feminist theories and activism. Many of the activities of some men's groups are evolving towards a more men-centred approach, mostly in the therapeutic sense. This was pointed out by many of the equality technicians in city councils in some of the meetings, and has apparently led to conflicts for having to finance activities of some of the groups without being sure if their view on gender is critical from a feminist point of view. In fact, contrary to what it could appear, not all men's groups affirm to have a fluid or constant relationship with feminist groups of activists. This relationship is sometimes limited to the equality departments in local governments, through the aforementioned technicians. Hence the risk of isolation from feminist practices is perceived as one of the most important drawbacks of the "men meet men" formula and remains one of the open-ended questions in the debates around men and feminism.

\subsection{Mixed experiences: men and women in social movements}

This questioning meets a particular moment in the Basque Country and Spain in which activism and activist groups are being re-defined (Observatorio Metropolitano Of Madrid, 2014; Gil, 2011; VVAA, 2014). Many activist groups (youth activist groups, left wing pro-independence groups, worker and student unions...) are starting to include more and more feminist demands in their programs and foundational statutes. Some of them are conducting processes to make the activities and structures of the organizations more compliant to feminist principles. As limited as these experiences are, they are generating quite a lot of debates on the role of men in feminist issues. Some find the mixed 
experiences of men and women useful and inspiring, but then again, the limits of the processes are being made visible by many feminist activists. They point out that the same power dynamics present in society are being reproduced by the activists in these processes. A crucial element in the course of those procedures in mixed groups seems to be that many of the women involved are as well feminist activists in all-women groups, and therefore feel a backing space for their actions and proposals in the mixed groups. Although ambivalent, there may be some clues worth considering in the current processes in mixed groups.

One of the questions arisen from those mixed experiences is the use of feminism as a nomenclature or terminology to refer to the groups. Some of the activist groups are defining their goals and principles as feminist (along with "socialist" or "anarchist", for example) accompanied by many men activists identifying themselves as feminists (in social media, meetings or interviews). Although positive since naming themselves as feminists can help reducing the negative stigma over feminism, some feminist activists have appointed that it may well respond to an urge to stick "the feminist label" on themselves by organizations and activists rather than reflecting deep changes in the structures of the organizations and activists' attitudes ${ }^{22}$.

\section{SOME BRIEF CONCLUSIONS}

It appears that discussing men and feminism is still more about opening questions than about closing them. All the debates presented above give us some account of the complexity of the issue and the need to deal with it and reflect on it from different points of view. Acknowledging its complexity instead of avoiding it and trying to look for easy formulas to offer can be essential.

Different aspects of the relationship between men and feminism remain problematic, and thinking about them in multiple and diffracted ways can help us elaborate a more exhaustive take on it. This entails thinking critically on the direction of masculinity studies and even to question the

22 Alice Jardine pointed out, already in 1984 and referring to the academic context, the suspicion of men having "read our demands but haven't adequately read our work" (stressed in the original as well) as a way to denounce the appropriation of feminist discourses by men without going in deep through them (Jardine and Smith, 1989:58). Many activists, mostly women, have expressed similar concerns during the debates and forums in which I took part. 
very need of them as such. Specially in the Basque and Spanish context where this branch of studies is still marginally developed, re-thinking the direction of those studies can be necessary if a trend towards identitycentred, power-blind studies is to be avoided. Not that it is not important to understand and study masculine identities and the way they are formed in current societies, but going further into elaborating a complex view would imply to study as well the way those identities are operating and moving themselves (and even displacing others) in the power-driven social arenas.

This vision on identities, subjectivities and power asks for points of departure and developments in research that cannot be limited to men and the details of their experience. Investing on integral approaches may help: including relational aspects and different types of data that do not limit the findings to the experience of men. The academia can actually have a lot to say in these debates by motivating models of research that embrace feminist political commitment. For this change to be possible and effective the actual forms of research and specially validation must be put on hold and new forms of objectivity (Haraway, 1995) have to be explored and implemented. All the same, the involvement of communities such as feminist movements and institutions must be thought of as ways of legitimizing research, too often set far aside from society's needs (Mclntyre, 2008).

Regarding social movements that aim for change in gender-based unequal power relationships, many aspects can be considered to envisage the relationship between men and feminism. First of all, the complexity of the position occupied by men who somehow commit to anti-sexism must be understood as inherent to the very position men occupy in society. The discomfort of not finding easy formulas must be then embraced and even encouraged, avoiding reassuring approaches and thinking uneasiness as an indispensable driving force.

Secondly, guaranteeing an in-depth contact with feminist theories and movements as well as other corpuses of though derived from LGBT, antiracist or civil rights movements can be a source of adding complexity to the debates on men and feminism and a fount of ideas and strategies to think about and consider. Debates such as political subjectivity, intersectional oppression, and inclusion or gender binaries can be some of the hints to be examined thoroughly. Maintaining direct contact with 
feminist activists and groups can also help avoiding the isolation of men's initiatives and the risk of self-referentiality.

Finally, the ways of participation must be thought of, first of all, by reviewing the ideas of action and activism, critically revisited by feminist and queer thinkers. Secondly by putting in question the formula of men's groups (or men-meet-men) as the only way of engagement for men, but at the same time considering the importance and contributions made by them. Exploring new forms for men to relate to feminist issues must avoid naivety and consider the risks of reproducing unbalanced power schemes when doing so.

\section{BibliografíA}

Arendt, H., 1998, The human condition, University of Chicago Press, Chicago.

Baxter, J., 2004, Positioning Gender in Discourse: A Feminist Methodology, Palgrave Macmillan, New York.

Bonino, L., 2000, "Varones, género y salud mental. Deconstruyendo la "normalidad" masculina", en A. Carabi y M. Segarra (Eds.), 2000, Nuevas masculinidades, Icaria, Barcelona.

Braidotti, R., 2000, Sujetos nómades: corporización y diferencia sexual en la teoría feminista contemporánea, Paidós, Buenos Aires.

Braidotti, R., 2004, Feminismo, diferencia sexual y subjetividad nomade, Gedisa, Barcelona.

Bridges, T., Pascoe, C.J., 2014. "Hybrid Masculinities: New Directions in the Sociology of Men and Masculinities", en Sociology Compass, 8, pp. 246-258.

Butler, J., 1993, Bodies that matter: on the discursive limits of "sex", Routledge, New York.

Butler, J., 2004, Undoing gender, Routledge, New York.

Butler, J., 2006, Gender trouble: feminism and the subversion of identity, Routledge classics, Routledge, New York.

Connell, R.W., 1995, Masculinities, Polity Press, Cambridge.

Connell, R.W., 1997. "La organización social de la masculinidad", en T. Valdés y J. Olavarría (Eds.), Masculinindad/es: poder y crisis. ISISFLACSO Internacional, Santiago de Chile, pp. 31-48. 
Crenshaw, K., 1991, "Mapping the Margins: Intersectionality, Identity Politics, and Violence against Women of Color", en Stanford Law Review, 43, pp. 1241-1299.

Defentsoria, 2003, Evolución del tiempo medio diario de la carga de trabajo total de mujeres y hombres (horas:minutos). CAE. 1998-2003, Gobierno Vasco, Vitoria-Gasteiz.

Duggan, L., 2003, The twilight of equality?: neoliberalism, cultural politics, and the attack on democracy, Beacon Press, Boston.

Epelde, E., Aranguren, M., Retolaza, I., 2015, Gure genealogia feministak. Euskal Herriko mugimendu feministaren kronika bat, Emagin Dokumentazio Zentrua, Pamplona.

Esteban, M.L., 2011, Critica del pensamiento amoroso, Bellaterra Edicions, Barcelona.

Esteban, M.L., Amurrio, M. (Eds.), 2010. Feminist challenges in the social sciences: gender studies in the Basque country, Current research series, Center for Basque Studies, University of Nevada, Reno.

Fausto-Sterling, A., 2000, Sexing the body: gender politics and the construction of sexuality, Basic Books, New York.

Foucault, M., 2009, La arqueología del saber, Siglo XXI, Madrid.

Galofre, P., 2014. "Pasar, iqué complicado!", en Pikara Magazine, publicado online el 29/05/2014, disponible en: http://www.pikaramagazine.com/2014/05/pasar-que-complicado/. Última consulta: 12/03/2015.

Garcés, M., 2013, Un mundo común, Bellaterra Edicions, Barcelona.

Gil, S.L., 2011, Nuevos feminismos. Sentidos comunes en la dispersión: una historia de trayectorias y rupturas en el Estado español, Traficantes de Sueños, Madrid.

Gil, S.L., 2015, "Hacer desde el «impasse»: feminismos, diferencias, crisis y política de lo común", en Diagonal Periódico, publicado online el 11/03/2015, disponible en:

https://www.diagonalperiodico.net/blogs/vidasprecarias/hacerdesde-impasse-feminismos-diferencias-crisis-y-politica-locomun.html. Última consulta: 11/03/2015.

Guzmán, P., Platero, R. (Lucas), 2012, “Passing, enmascaramiento y estrategias identitarias: diversidades funcionales y sexualidades nonormativas", en R. (Lucas) Platero (Ed.), Intersecciones, cuerpos y sexualidades en la encrucijada, Bellaterra Edicions, Barcelona, pp. 125-158. 
Haraway, D.J., 1995, Ciencia, cyborgs y mujeres: la reinvención de la naturaleza, Editorial Cátedra y Universitat de València, València.

Hoppe, T. (Ed.), 2008, Beyond Masculinty. Essays by queer men on gender and politics, disponible en: http://www.beyondmasculinity.com/. Última consulta: 12/03/2015.

Jardine, A., Smith, P., 1989, Men in feminism, Routledge, New York.

Lazar, M.M., 2007, "Feminist Critical Discourse Analysis: Articulating a Feminist Discourse Praxis", en Critical Discourse Studies, 4, pp. 141164.

Lorde, A., 2007, Sister outsider: essays and speeches, Crossing Press, Berkeley.

Lupton, D., 1998, The emotional self: a sociocultural exploration, Sage, London.

Mackenzie, C., Stoljar, N. (Eds.), 1999, Relational autonomy: feminist perspectives on automony, agency, and the social self, Oxford University Press, New York.

McIntyre, A., 2008, Participatory Action Research. Sage, London.

Observatorio Metropolitano Of Madrid, 2014, Crisis and revolution in Europe. People of Europe, rise up!, Traficantes de Sueños, Madrid.

Platero, R. (Lucas) (Ed.), 2012, Intersecciones: cuerpos y sexualidades en la encrucijada, Bellaterra, Barcelona.

Seidler, V.J., 2006, Masculinidades: culturas globales y vidas intimas, Montesinos, España.

Spivak, G.C., 1996, The Spivak reader: selected works of Gayatri Chakravorty Spivak, Routledge, New York.

Villarroya, A.A., Goig, R.L., 2003, “Asociacionismo heterogéneo, voluntariado diverso", en Revista de Estudios de Juventud, 1, pp. 173191.

VVAA, 2014, Dabilen harriari goroldiorik ez. Militantziaz eta horizontaltasunaz hausnartzen, Joxemi Zumalabe Foundation, Bilbao.

Zabala, B., 2008, Movimiento de mujeres: mujeres en movimiento, Txalaparta, Tafalla, Navarra. 